\title{
Quercetin ameliorates A 3 toxicity in Drosophila AD model by modulating cell cycle-related protein expression
}

\author{
Yan Kong ${ }^{1}$, Ke Li ${ }^{2}$, Tingting Fu ${ }^{3}$, Chao Wan ${ }^{4}$, Dongdong Zhang ${ }^{4}$, Hang Song ${ }^{4}$ Yao \\ Zhang ${ }^{4}$, Na Liu ${ }^{4}$, Zhenji Gan ${ }^{3}$ and Liudi Yuan ${ }^{1,4}$ \\ ${ }^{1}$ Department of Biochemistry and Molecular Biology, Medical School, Southeast University, Nanjing, Jiangsu, China \\ ${ }^{2}$ Gladstone Institute of Cardiovascular Disease and Department of Pharmaceutical Chemistry, University of California, San \\ Francisco, CA, USA \\ ${ }^{3}$ MOE Key Laboratory of Model Animal for Disease Study, Model Animal Research Center, Nanjing University, Nanjing, China \\ ${ }^{4}$ State Education Ministry's Key Laboratory of Developmental Genes and Human Diseases, Institute of Life Sciences, \\ Southeast University, China
}

Correspondence to:Liudi Yuan, email: yld@seu.edu.cn

Zhenji Gan, email: ganzj@nicemice.cn

Yan Kong, email: kongyancn@163.com

Keywords: quercetin, Drosophila, Alzheimer's disease, cell cycle, DNA replication, Gerotarget

Received: September 22, 2015 Accepted: September 01, $2016 \quad$ Published: September 10, 2016

\section{ABSTRACT}

Alzheimer's disease (AD) is a prevalent neurodegenerative disorder characterized by $\beta$ amyloid $(A \beta)$ deposition and neurofibril tangles. It has been reported that a bioflavonoid, quercetin, could ameliorate AD phenotypes in $C$. elegans and mice. However, the mechanism underlying the ameliorative effect of quercetin is not fully understood yet. Drosophila models could recapitulate AD-like phenotypes, such as shortened lifespan, impaired locomotive ability as well as defects in learning and memory. So in this study, we investigated the effects of quercetin on AD in Drosophila model and explored the underlying mechanisms. We found quercetin could effectively intervene in AD pathogenesis in vivo. Mechanism study showed quercetin could restore the expression of genes perturbed by $A \beta$ accumulation, such as those involved in cell cycle and DNA replication. Cyclin B, an important cell cycle protein, was chosen to test whether it participated in the AD ameliorative effects of quercetin. We found that cyclin B RNAi in the brain could alleviate AD phenotypes. Taken together, the current study suggested that the neuroprotective effects of quercetin were mediated at least partially by targeting cell cycle-related proteins.

\section{INTRODUCTION}

Alzheimer's disease is a prevalent neurodegenerative disorder that mainly affects the elderly population. Its pathological features include senile plaques formed by $A \beta$ deposition and neurofibril tangles composed of hyper-phosphorylated microtube associated tau protein [1]. A $\beta$ is derived from amyloid protein precursor (APP) which should be sequential processed by $\beta$ secretase (BACE1) and $\gamma$ secretase [2]. $\gamma$ secretase is a protease complex formed by presenilin $1 / 2$ (PS1/2), nicastrin, anterior pharynx-defective 1 (APH-1) and presenilin enhancer 2 (PEN-2) [3]. Mutations of APP and/or PS1/2 are usually found in early onset familial AD. However, the majority of $\mathrm{AD}$ cases are sporadic and late-onset. Its etiology is still elusive. Further investigation is required to elucidate detailed mechanisms and develop effective therapeutic methods. With short lifespan and convenience for genetic manipulation, Drosophila is extensively used in research for aging and aging related neurodegeneration $[4,5]$. Drosophila AD models have been established by expressing human wildtype or Arctic mutant $A \beta_{42}$ in central nervous systems $[6,7]$. These flies demonstrate shorter lifespan, impaired locomotive ability and defects in learning and memory [6]. Drosophila models are widely used in exploring molecular mechanisms for $\mathrm{AD}$ pathogenesis and screening for anti-Alzheimer drugs [8].

Natural and chemically synthesized small molecules targeting important signaling pathways are widely used in research and clinic $[9,10]$. Quercetin is a 
flavonoid enriched in plants such as onions, apples and tea. With the effects of antioxidant, radical-scavenging, antiinflammation and anti-proliferation, quercetin has been reported to have the potential for treatments of cancer, cardiovascular disease, diabetes, infection, inflammation and neurodegeneration [11-15]. Quercetin protects primary neurons and hippocampal cultures against $A \beta_{42}$ toxicity in vitro $[16,17]$. In addition, quercetin could also ameliorate $\mathrm{AD}$ phenotypes in vivo. It could activate protein degradation pathways and protect $C$. elegans from $\mathrm{A} \beta_{42}$ induced paralysis [18]. In aged triple transgenic $\mathrm{AD}$ mice $(3 \mathrm{xTg}-\mathrm{AD})$, quercetin decreases extracellular $\beta$-amyloidosis, tauopathy, astrogliosis and microgliosis in the hippocampus and the amygdala [19]. However, the detailed mechanism underlying the ameliorative effect of quercetin on AD is not fully understood yet.

Quercetin used in our study was purified from the flowers of Styphnolobium japonicum, one of the 50 fundamental herbs used in traditional Chinese medicine [20]. Using Drosophila AD models, we found that quercetin could extend the lifespan and rescue locomotive defects of AD flies. Transcriptomic analysis showed that several signaling pathways such as cell cycle proteins in FoxO signaling pathway and DNA replication were dysregulated in AD flies. Interestingly, dietary quercetin supplementation could restore $A \beta$ induced perturbation on these pathways. Further experiments using in vivo RNAi of the cell cycle protein cyclin B in the brain ameliorated AD phenotypes, which confirmed that the beneficial effects of quercetin in AD was mediated by targeting cell cycle related proteins. In conclusion, our study validated the theory that ectopic cell cycle events could mediate neurodegeneration and confirmed that neurons exhibited biomarkers of cell cycle progression and DNA replication in AD brains using Drosophila model. Moreover, we revealed quercetin as a potential chemical to rescue AD phenotypes by acting on the expression of genes related to cell cycle events.

\section{RESULTS}

\section{Quercetin rescued AD phenotypes in Drosophila model}

As reported previously, we established Drosophila AD model by driving Arctic $A \beta_{42}$ expression in the brain $[6,7]$. Specifically, elav-Gal4 virgins were crossed with UAS-Arctic $A \beta_{42}$ males to induce pan-neuronal transgene expression in the offspring. We found AD flies recapitulated shorter lifespan and impaired locomotive behavior. Quercetin used in this study was extracted from Styphnolobium japonicum flowers. HPLC analysis

A

B
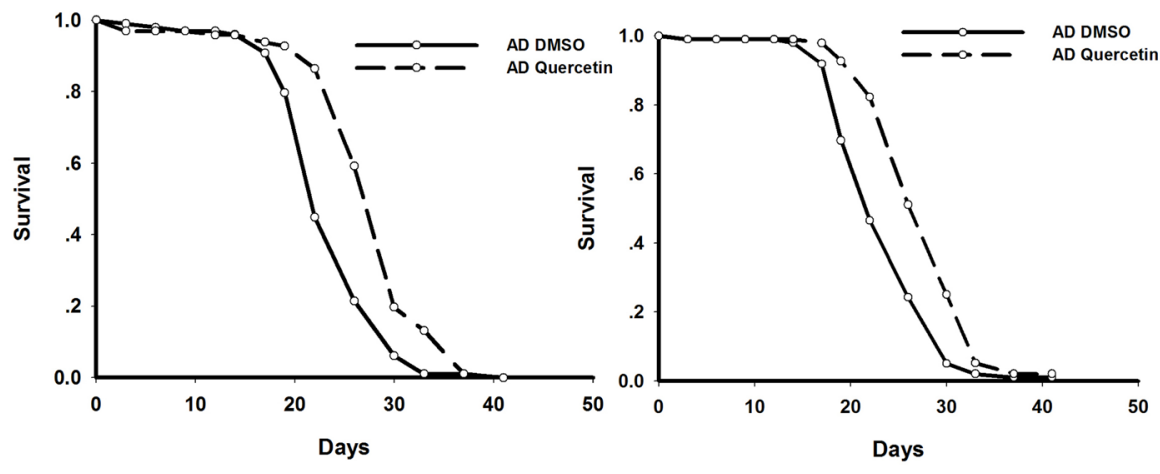

C

D
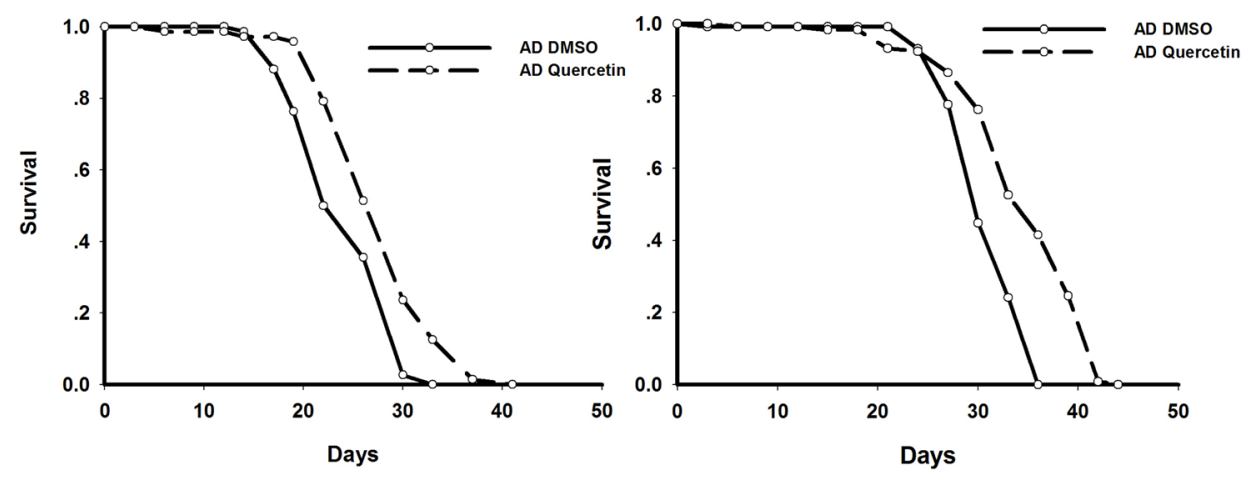

Figure 1: Quercetin extended lifespan of $\boldsymbol{A D}$ Drosophila. Representative results from 4 independent experiments were shown. Survival curves were compared using the log-rank test $(P<0.05$ between AD DMSO and AD Quercetin flies). 
Table 1: Dysregulated pathways in AD flies as compared with WT Drosophila.

\begin{tabular}{|c|c|c|}
\hline Pathway & genes & up or down regulated \\
\hline DNA replication & $\mathrm{Mcm} 7, \mathrm{Mcm} 3, \mathrm{PCNA}, \mathrm{Mcm} 2$ & up \\
\hline FoxO signaling pathway & CycB, CG10924, polo, CycB3 & up \\
\hline Lysine degradation & Su, CG10814 & down \\
\hline Hypoxia response via HIF activation & dhd & up \\
\hline De novo pyrimidine deoxyribonucleotide biosynthesis & RnrS & up \\
\hline Pentose and glucuronate interconversions & UGP, Ugt86Dd & down \\
\hline Oxidative stress response & dhd & up \\
\hline Starch and sucrose metabolism & UGP ,Ugt86Dd & down \\
\hline p53 pathway & CycB & up \\
\hline De novo purine biosynthesis & RnrS & up \\
\hline Nitrogen metabolism & CG18673 & up \\
\hline Base excision repair & PCNA & up \\
\hline Mismatch repair & PCNA & up \\
\hline FGF signaling pathway & a5 & down \\
\hline EGF receptor signaling pathway & a5 & down \\
\hline Dorso-ventral axis formation & orb & up \\
\hline Glycine, serine and threonine metabolism & Gld & up \\
\hline Ascorbate and aldarate metabolism & Ugt86Dd & down \\
\hline Retinol metabolism & Ugt86Dd & down \\
\hline Galactose metabolism & UGP & down \\
\hline Nucleotide excision repair & PCNA & up \\
\hline Porphyrin and chlorophyll metabolism & Ugt86Dd & down \\
\hline Citrate cycle (TCA cycle) & CG10924 & up \\
\hline Amino sugar and nucleotide sugar metabolism & \begin{tabular}{|l|l} 
UGP \\
\end{tabular} & down \\
\hline Pyruvate metabolism & CG10924 & up \\
\hline Drug metabolism - other enzymes & Ugt86Dd & down \\
\hline Glycolysis /Gluconeogenesis & CG10924 & up \\
\hline Drug metabolism -cytochrome P450 & Ugt86Dd & down \\
\hline Metabolism of xenobiotics by cytochrome P450 & Ugt86Dd & down \\
\hline Glutathione metabolism & RnrS & up \\
\hline Phagosome & alphaTub67C & up \\
\hline Pyrimidine metabolism & RnrS & up \\
\hline Ubiquitin mediated proteolysis & APC7 & up \\
\hline Purine metabolism & RnrS & up \\
\hline \multirow{2}{*}{ Metabolic pathways } & Gld, RnrS, CG10924 & up \\
\hline & Ugt86Dd,UGP & down \\
\hline
\end{tabular}

showed $97.686 \%$ of the extract was quercetin dehydrate (Figure S1). We also performed mass spectrometry and ${ }^{13} \mathrm{C}$ NMR to analyze the extract. The results of molecular weight and chemical structure further verified quercetin we used (Figure S2 and S3). Dietary supplementation of quercetin $(0.44 \mathrm{~g} / \mathrm{L}$ in standard sugar-yeast medium $)$ from adulthood dramatically and consistently extended lifespan of AD Drosophila in independent experiments (Figure 1). In addition, it could also rescue impairments in climbing ability (Figure 2). Taken together, our results indicated that quercetin could ameliorate $\mathrm{A} \beta$ toxicity in vivo.

\section{A $\beta$ neurotoxic effects were mediated by cell cycle related signaling pathways in vivo}

In order to investigate the underlying mechanisms for quercetin neuroprotective effects against $\mathrm{A} \beta$, 
transcriptomic analysis was performed by Affymetrix Drosophila Genome 2.0 Array (Figure S4). At day 10 post eclosion, AD flies showed impaired climbing ability while their survival was unchanged. We chose female flies at this time point for transcriptomic analysis. Robust multi-array average (RMA) method was used to identify differentially expressed genes (ratio $\geq 2$ or $\leq 0.5$ ). We found 47 transcripts were downregulated while 105 transcripts were increased in $\mathrm{AD}$ flies when compared with WT (elav $>$ w1118) group. Gene ontology (GO) analysis was performed to classify dysregulated genes into different functional categories. Top 20 clusters were shown in Figure 3A.

Pathway enrichment analysis showed that DNA replication and cell cycle proteins in FoxO signaling pathway were significantly influenced by $A \beta$ expression (Figure 3B). These results were highly consistent with GO analysis which showed cell cycle and DNA replication were perturbed in AD flies. Dysregulated genes involved in these pathways were listed in Table 1 .

\section{Quercetin could restore signaling pathways interrupted by $\mathrm{A} \beta$ expression}

In order to investigate the mechanism underlying quercetin's beneficial effects on AD Drosophila, we

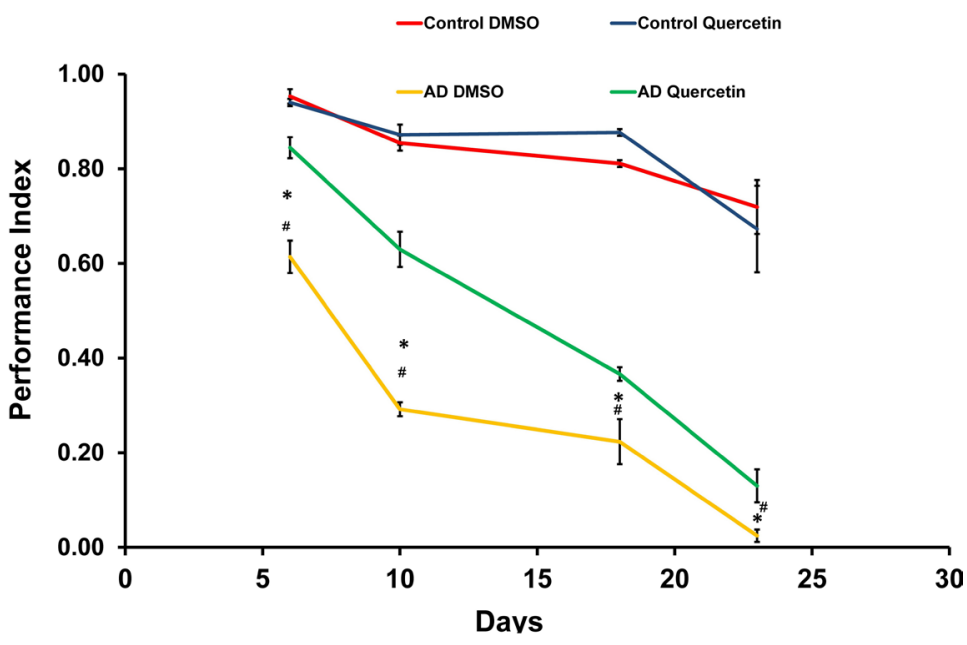

Figure 2: Quercetin ameliorated impaired climbing ability of $\boldsymbol{A D}$ Drosophila. Climbing abilities were presented as the average performance index $(\mathrm{PI}) \pm \mathrm{SEM}(* P<0.05$ between Control DMSO and AD DMSO flies. $\# P<0.05$ between AD DMSO and AD Quercetin flies).

A

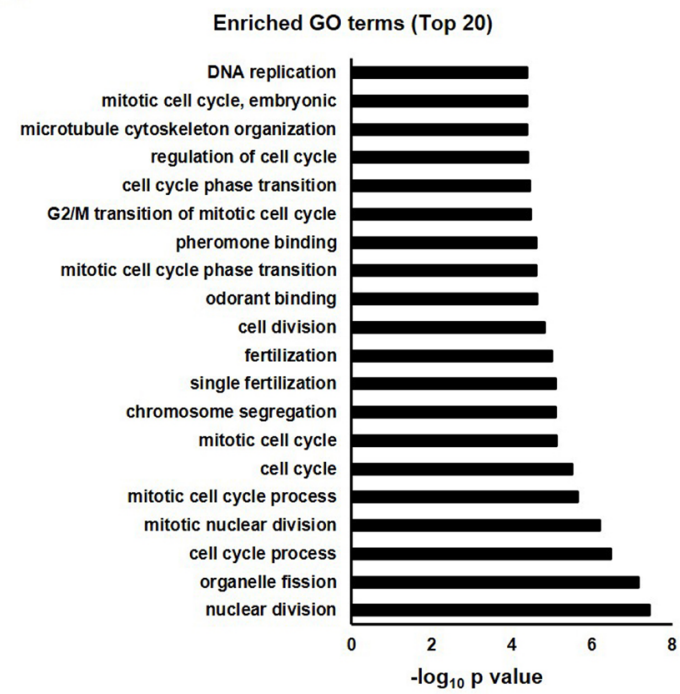

B

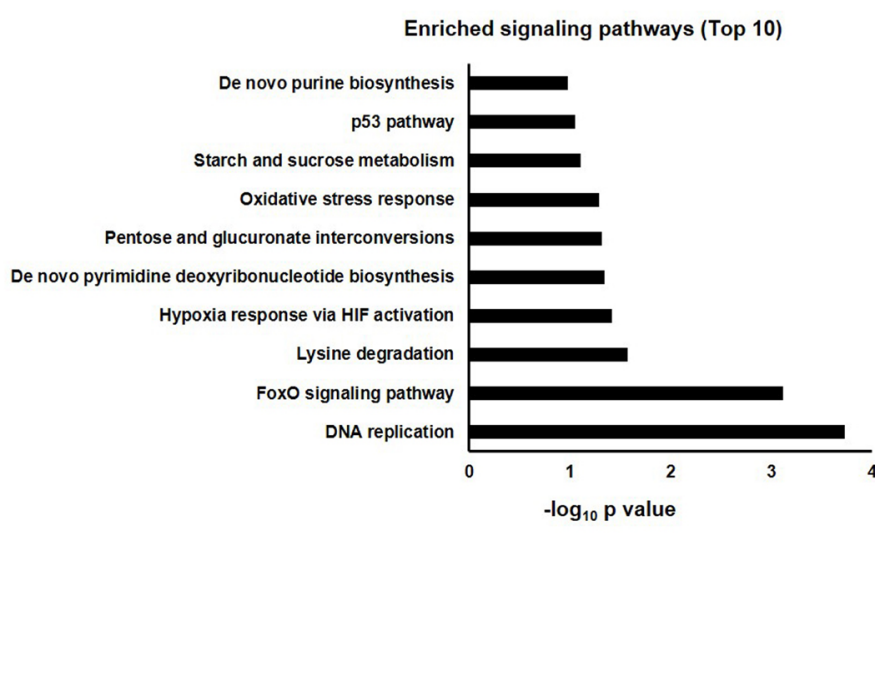

Figure 3: GO annotation and pathway enrichment of dysregulated genes in AD flies as compared with WT (AD vs. WT). A. Functional annotations were performed to analyze dysregulated genes in biological process, molecular function and cell component in AD Drosophila. Top $20 \mathrm{GO}$ terms were shown and displayed as $-\log _{10} P$ values. B. Dysregulated genes were analyzed by KEGG pathway, PID Curated, PID BioCarta, PID Reactome, BioCyc, Reactome and Panther. Top 10 enriched pathways were shown and displayed as $-\log _{10} P$ values. 
Table 2: Dysregulated pathways in AD flies rescued by quercetin treatment.

\begin{tabular}{|l|l|l|}
\hline Pathway & genes & $\begin{array}{l}\text { Up or down regulated by quercetin in AD } \\
\text { flies }\end{array}$ \\
\hline DNA replication, & Mcm7, Mcm3, PCNA, Mcm2 & down \\
\hline FoxO signaling pathway & CycB, polo, CycB3 & down \\
\hline Hypoxia response via HIF activation & dhd & down \\
\hline $\begin{array}{l}\text { De novo pyrimidine deoxyribonuleotide } \\
\text { biosynthesis }\end{array}$ & RnrL & down \\
\hline Oxidative stress respose & dhd & down \\
\hline p53 pathway & CycB & down \\
\hline De novo purine biosynthesis & RnrL & down \\
\hline Unbiquitin mediated proteolysis & fzy, APC7 & down \\
\hline Mismatch repair & PCNA & down \\
\hline Base exicision repair & PCNA & down \\
\hline Doso-vental axis formation & orb & down \\
\hline Nucleotide excision repair & PCNA & down \\
\hline Glutathion metabolism & RnrL & down \\
\hline Pyrimide metabolism & RnrL & down \\
\hline Purine metabolism & RnrL & down \\
\hline Metabolic pathways & RnrL, CG1673, CG5966 & down \\
\hline
\end{tabular}

compared gene expression profiles of AD flies fed with quercetin (AD Quercetin) or control food (AD DMSO) for 10 days. We found 5 transcripts were upregulated while 74 transcripts were suppressed. Gene ontology analysis showed that a plethora of clusters in biological process, cell component and molecular function which had been interrupted in $\mathrm{AD}$ flies were reversed by quercetin (Figure 4A). GO enrichment hierarchy of molecular function demonstrated that, compared with control flies, differentially expressed genes in $\mathrm{AD}$ flies were enriched in clusters related to cyclin-dependent protein serine/threonine kinase regulator activity, 3'-5' DNA helicase activity and pheromone binding (Figure 5A). Interestingly, when we analyzed GO enrichment hierarchy of molecular function for quercetin targeting genes in $\mathrm{AD}$ flies, clusters including cyclin-dependent protein serine/ threonine kinase regulator activity and 3'-5' DNA helicase activity were also identified as enriched terms (Figure 5B). Pathway analysis showed that DNA replication and cell cycle proteins in FoxO signaling pathway were the most enriched pathways targeted by quercetin in AD flies (Figure 4B).

Comparing the data of $\mathrm{AD} v s$. WT and $\mathrm{AD}$ Quercetin vs. AD DMSO, we found the expression of $59 \mathrm{~A} \beta$ upregulated transcripts (58 genes) and $2 \mathrm{~A} \beta$ suppressed genes were restored by quercetin feeding (Figure 6). Quercetin restored the perturbation induced by $\mathrm{A} \beta$ on genes in 16 pathways, including DNA replication, cell cycle proteins in FoxO signaling pathway, Hypoxia response via HIF activation, De novo pyrimidine deoxyribonucleotide biosynthesis, Oxidative stress response and p53 pathway. Quercetin targets in these pathways were listed in Table 2. Collectively, these results indicated that quercetin could effectively restore genes related with cell cycle and DNA replication in AD Drosophila.

In order to confirm our findings, we selected 7 genes including cyclin $\mathrm{B}$, cyclin $\mathrm{B} 3$, polo, $\mathrm{mcm} 2, \mathrm{mcm} 3$, $\mathrm{mcm} 7$ and dhd to validate whether the $A \beta$ induced targets dysregulation could be restored by quercetin. Cyclin B, cyclin B3 and polo are cell cycle proteins in FoxO signaling pathway. Additionally, $\mathrm{mcm} 2, \mathrm{mcm} 3$ and $\mathrm{mcm} 7$ are DNA helicases essential for DNA replication. The qPCR results were consistent with microarray data (Figure 7A). As most of the dysregulated Drosophila genes do not have commercially available antibodies, we could only validate the protein level of cyclin B by western blot. The cyclin B antibody was obtained from Santa Cruz Biotechnology (sc-15872) and has been proved to be specific and sensitive for western blot [21]. Consistent with mRNA expression, cyclin B protein level was increased in the brain of AD Drosophila and restored after feeding with quercetin (Figure 7B).

\section{Protein-protein interaction network for transcriptomic results}

In order to explore the possible protein-protein interaction between dysregulated genes induced by $\mathrm{A} \beta$, STRING (http://string-db.org/), a database of known and predicted protein interactions was used to analyze microarray data [22]. As shown in Figure 8A, cyclin B (cycB), cyclin B3 (cycB3), polo, $\mathrm{mcm} 2, \mathrm{mcm} 3, \mathrm{mcm} 7$ and mus209 (PCNA) were hubs of the network and 
Enriched GO terms (Top 20)

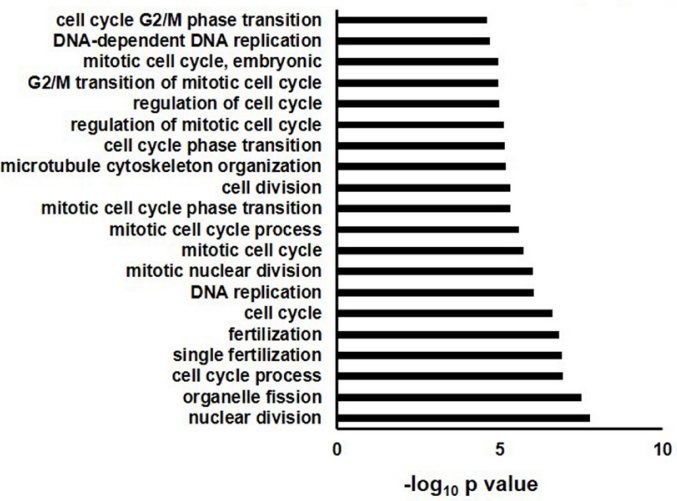

Enriched signaling pathway (Top 10)

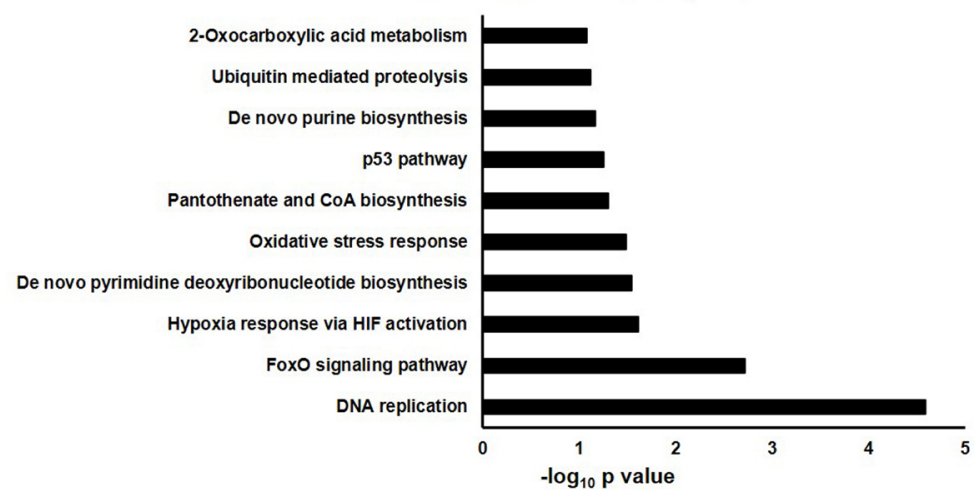

Figure 4: GO annotation and pathway enrichment of differentially expressed genes in AD flies treated with quercetin or control food (AD Quercetin vs. AD DMSO). A. Functional annotations were performed to analyze differentially expressed genes in biological process, molecular function and cell component in AD Drosophila fed with quercetin or control food. Top 20 GO terms were shown and displayed as $-\log _{10} P$ values. B. Differentially expressed genes were analyzed by KEGG pathway, PID Curated, PID BioCarta, PID Reactome, BioCyc, Reactome and Panther. Top 10 enriched pathways were shown and displayed as $-\log _{10} P$ values.
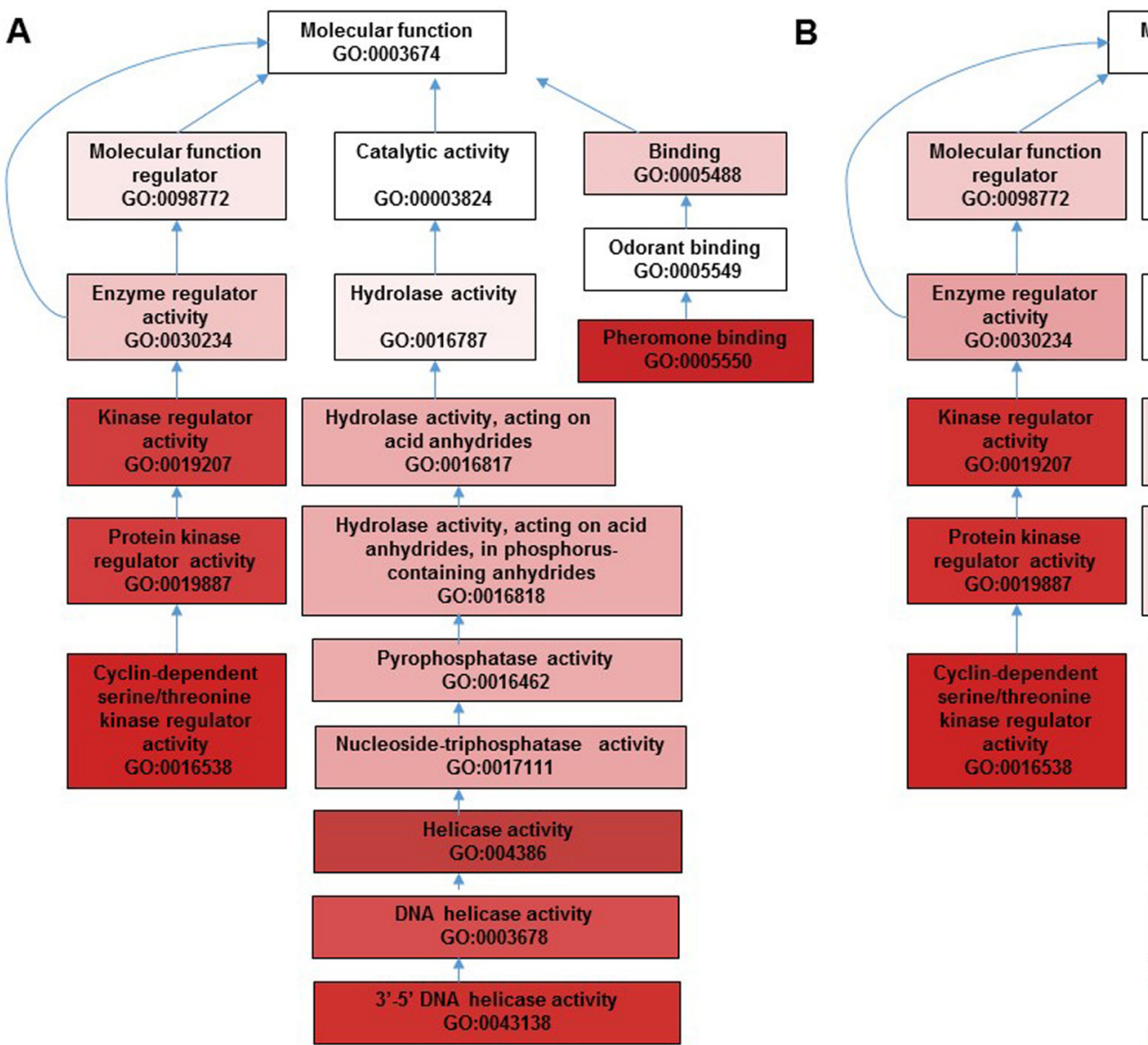
Molecular function GO:0003674
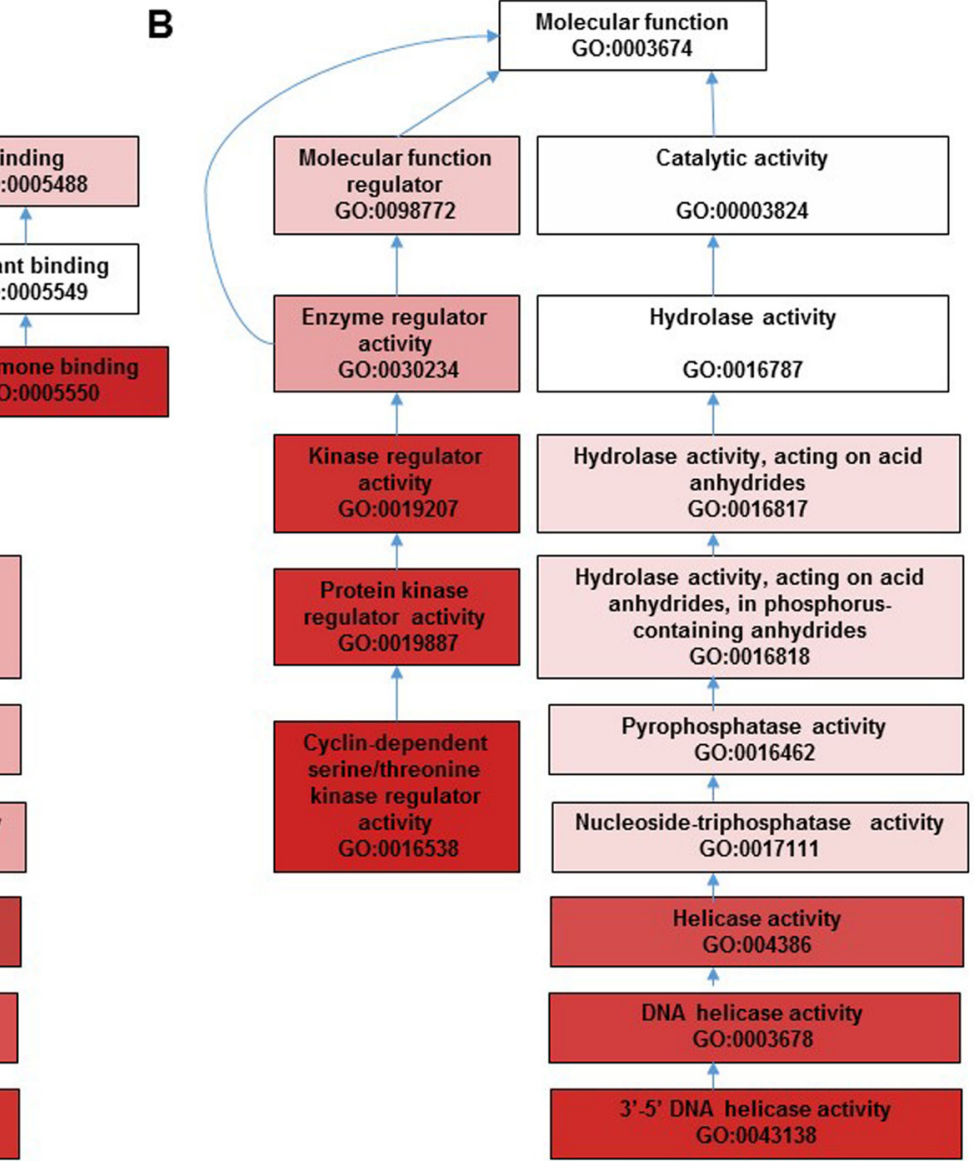

Figure 5: GO enrichment hierarchy for terms interaction in molecular function for dysregulated genes in AD vs. WT and AD Quercetin vs. AD DMSO. 
interact with other dysregulated proteins through direct or indirect manner. These nodes interacted with each other as shown in the figure. The results indicated that cell cycle related genes served as nodes and collaborated with other dysregulated proteins to form networks and mediate $A \beta$ toxicity in Drosophila.

Protein-protein interaction network for quercetin targeted genes in AD Drosophila was also analyzed by STRING. Interestingly, protein-protein interaction networks were consistent with that of AD vs. WT which identified cycB, cycB3, polo, mcm $2, \operatorname{mcm} 3, \operatorname{mcm} 7$ and mus209 (PCNA) as hubs of the network and collaborating with other proteins (Figure 8B). It indicated that quercetin could ameliorate $\mathrm{AD}$ phenotypes by rescuing cell cycle related signaling pathways and protein interaction networks.

\section{Inhibition of cell cycle protein cyclin B could ameliorate $A D$ phenotypes}

As an important cell cycle protein and hub of protein-protein interaction networks mentioned above, cyclin B was chosen to further validate our hypothesis. In order to verify our conclusion, cyclin B RNAi in the brain were induced by RU486 in adult-onset AD Drosophila. We crossed elav-GeneSwitch (ElavGS) line with flies carrying cyclin B siRNA and Arctic $A \beta_{42}$. The offspring will not express siRNA and $A \beta$ in absence of Mifepristone (RU486, RU). We transferred these flies to RU foods after eclosion and cyclin B siRNA expression would be induced in pan-neuronal manner together with $\mathrm{A} \beta$, which could rule out their effects on development. We found that knocking down cyclin B expression could effectively extend the lifespan and improve locomotive defects (Figure 9). Taken together, our results indicated that quercetin could ameliorate $\mathrm{AD}$ pathogenesis by targeting cell cycle related pathways perturbed by $\mathrm{A} \beta$ overexpression.

\section{DISCUSSION}

Quercetin has been reported to inhibit $\mathrm{A} \beta$ toxicity in vitro and in vivo. However, the detailed mechanisms are still elusive. Using Drosophila models, we found quercetin could extend lifespan and rescue climbing ability of AD flies, suggesting its potential therapeutic application in AD. Transcriptomic profiling and functional annotation analysis showed that cell cycle related proteins were interrupted by A $\beta$. Gene ontology analysis showed these genes were enriched in terms related to cell cycle and DNA replication. These terms interact with each other to form hierarchies. Further analysis using STRING

\section{Dysregulated genes in AD flies Genes regulated by quercetin in AD flies}

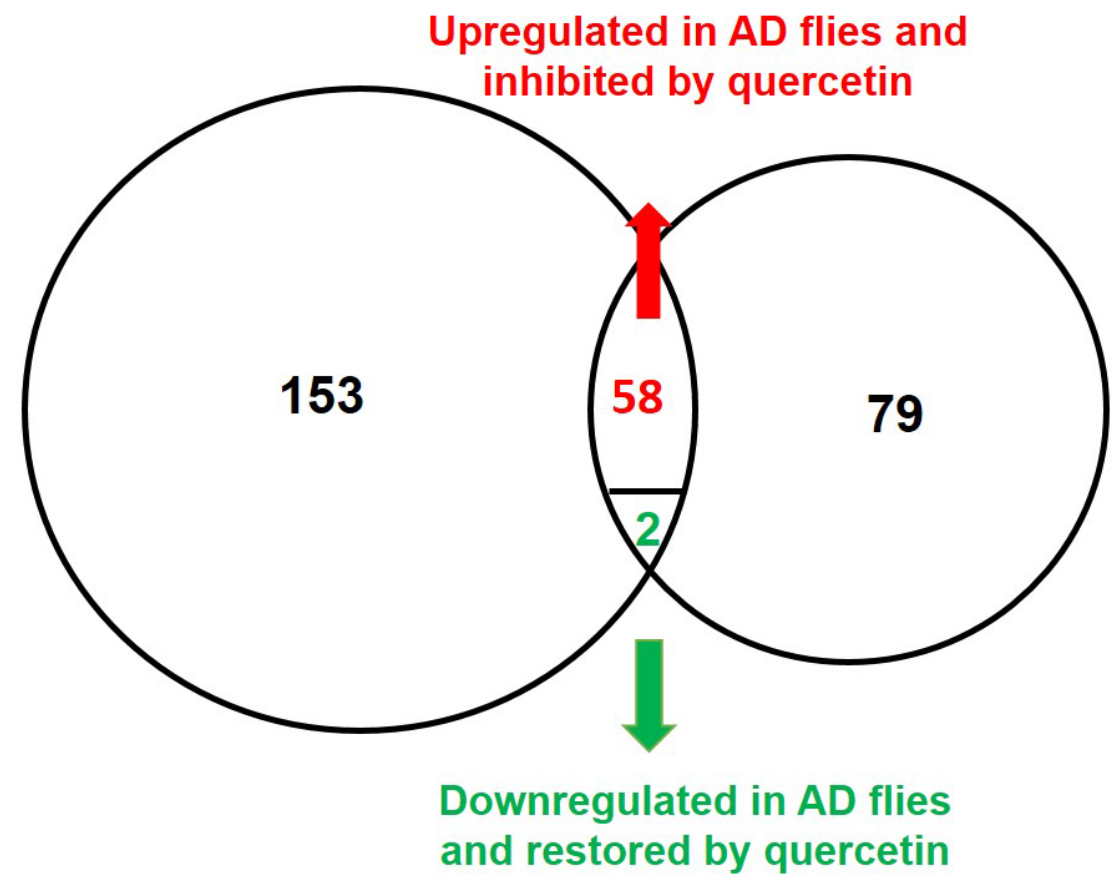

Figure 6: Venn diagram of genes dysregulated in AD flies and rescued by quercetin. 153 transcripts were dysregulated in AD flies as compared with control. The expression of 79 transcripts were influenced by quercetin in AD flies. When these results were combined together, it indicated that $58 \mathrm{~A} \beta$ induced and $2 \mathrm{~A} \beta$ suppressed genes were restored by quercetin. 
database showed that proteins in these pathways formed a network which contributed to AD pathogenesis. Dietary supplementation of quercetin could rescue these cell cycle related signaling pathways to ameliorate $\mathrm{AD}$ phenotypes.

The mechanisms for the beneficial effects of quercetin in $\mathrm{AD}$ could be explained in several aspects. By inhibition of BACE1-mediated cleavage of APP, quercetin suppresses $\beta$-amyloid synthesis in cell-free, cell-based and in silico studies [23].Using primary Tg2576 $\mathrm{AD}$ mouse neurons, quercetin metabolite quercetin-3-O- glucuronide has been proved to significantly reduce the generation of $\beta$-amyloid [24]. In addition to $A \beta$ synthesis, quercetin inhibits formation and extension of $A \beta$ fibrils and stimulates destabilization of preformed $A \beta$ fibrils $[25$, 26]. Quercetin-3-O-glucuronide has also been identified to interfere with the initial protein-protein interaction of $\mathrm{A} \beta_{40}$ and $\mathrm{A} \beta_{42}$ which is necessary for $\mathrm{A} \beta$ oligomerization [24]. Oxidative stress is usually found in AD cases and believed to contribute to disease progression. As a potent antioxidant, quercetin is able to effectively clear reactive

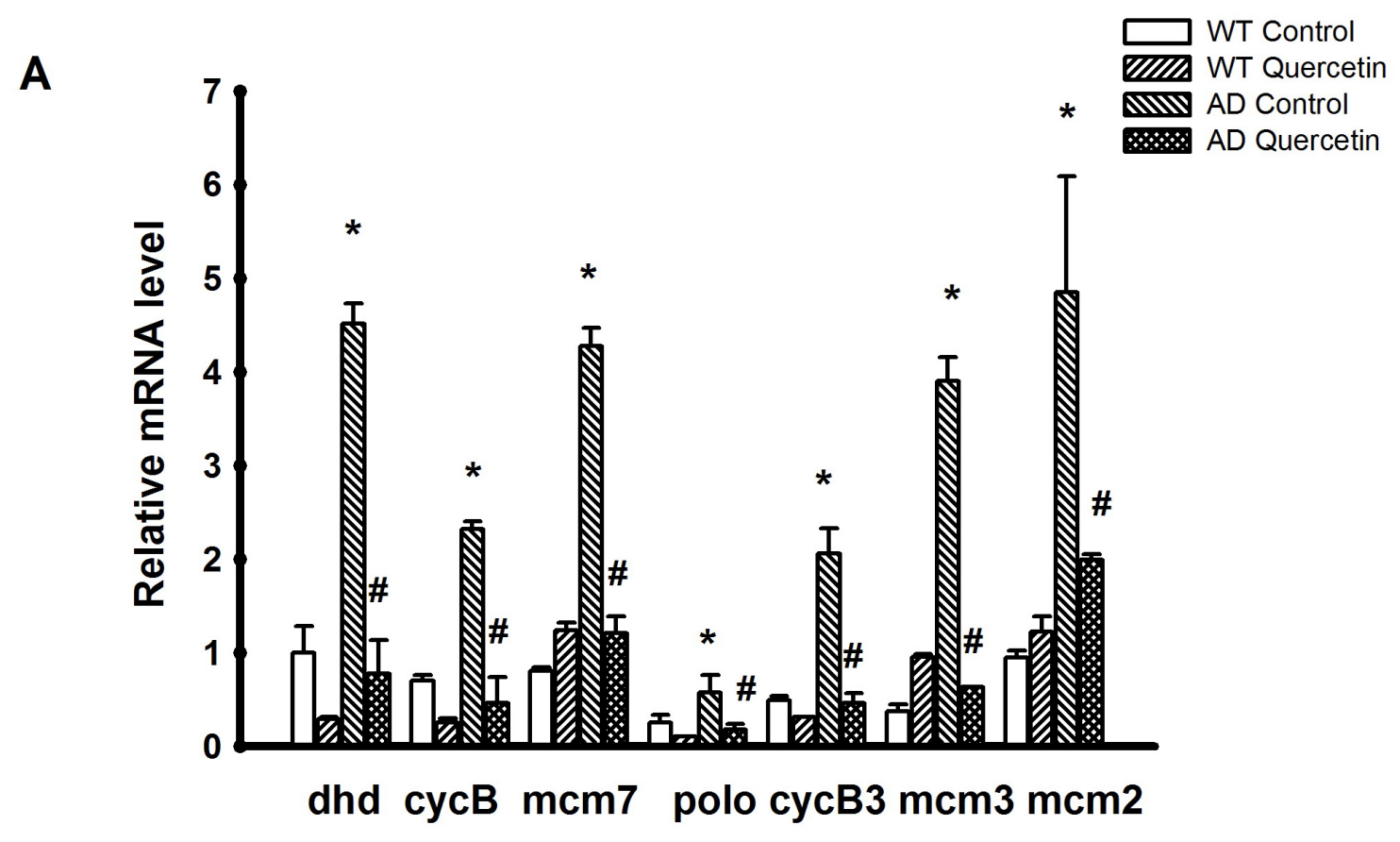

B WT Control AD Control

AD Quercetin

cyclin B

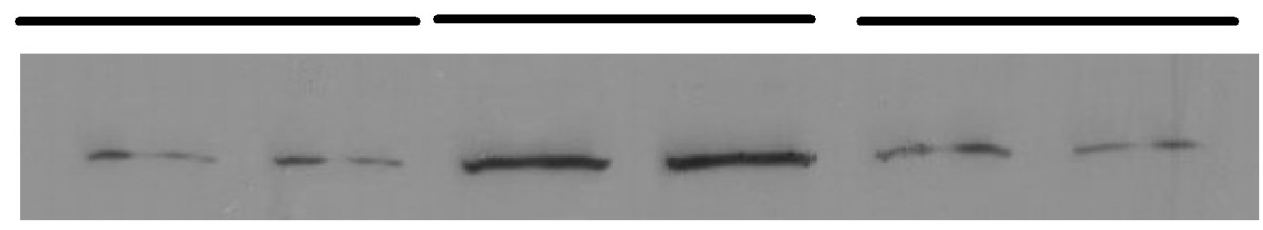

\section{Tubulin}

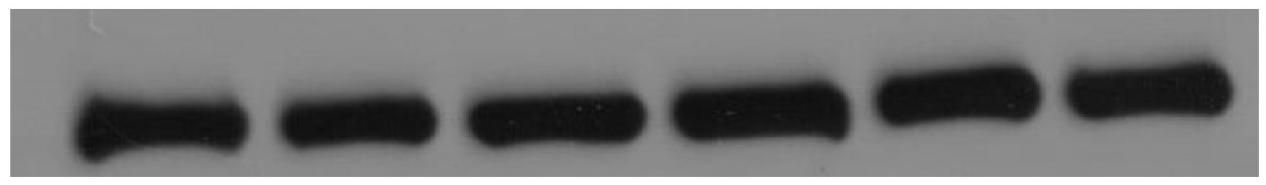

Figure 7: Validation of microarray results by qRT-PCR and Western blot. A. The mRNA levels of dhd, cyclin B, mcm2, $\mathrm{mcm} 3, \mathrm{mcm} 7$, cyclin B3 and polo were measured in WT and AD flies treated with quercetin or control food. The data was presented as the average \pm SEM ( $* P<0.05$ between WT Control and AD Control flies. $\# P<0.05$ between AD Control and AD Quercetin flies). B. Western immunoblot analysis of cyclin B and $\alpha$-tubulin using the indicated antibodies. Representative results from three independent experiments are shown. 


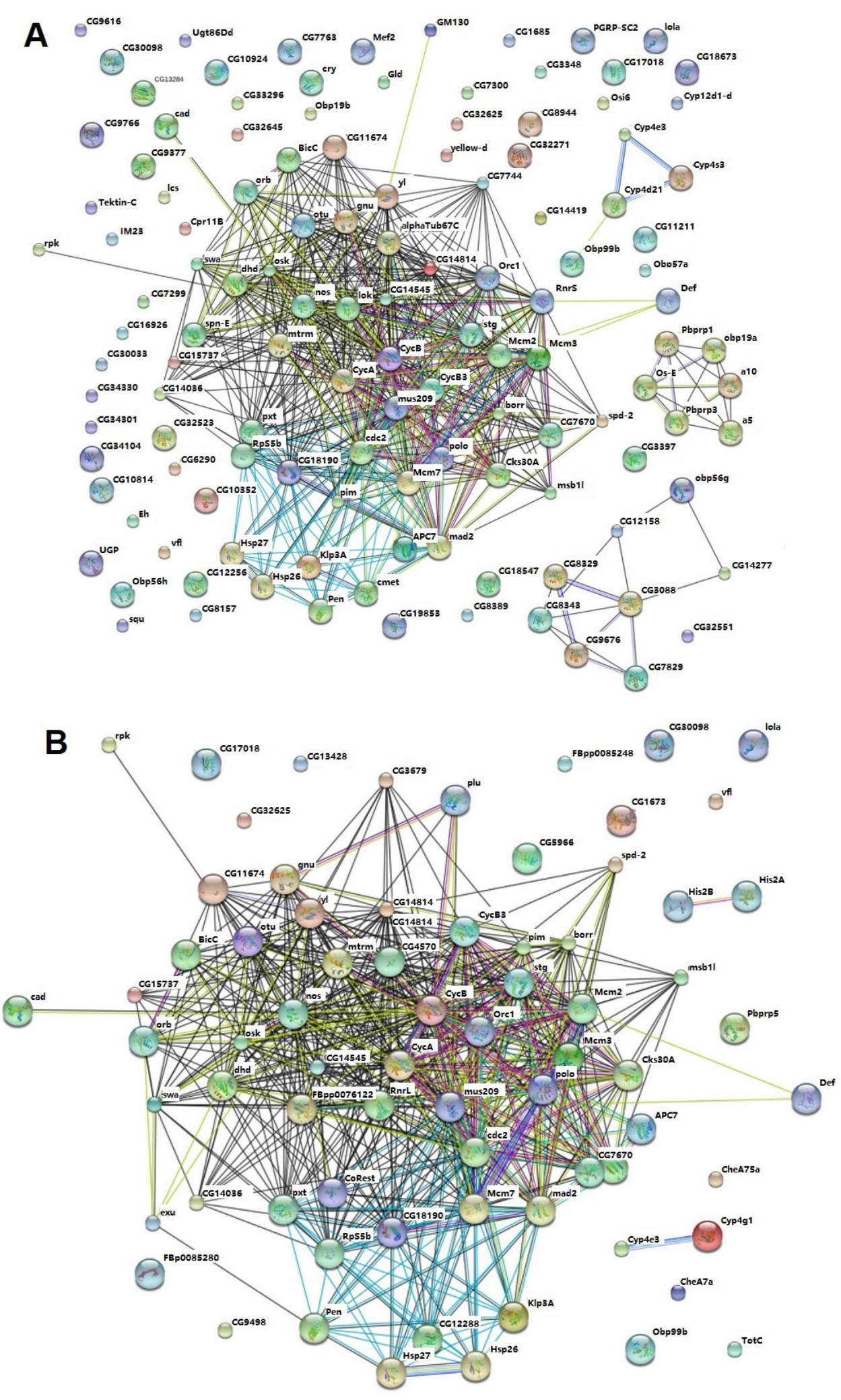

Figure 8: STRING analysis of the relationship between differentially expressed genes. A. The differentially expressed (DE) genes between AD and WT flies were analyzed using the STRING database. The network nodes represent the proteins encoded by the DE genes. Lines linking nodes with different colored represent types of evidence used in predicting (red line: fusion evidence; green line: neighborhood evidence; blue line: coocurrence evidence; purple line: experimental evidence; yellow line: textmining evidence; light blue line: database evidence; black line; coexpression evidence). B. The DE genes between AD Quercetin and AD DMSO were analyzed using the STRING database as described above. 
oxygen species which could be beneficial to $\operatorname{AD}[27,28]$. Quercetin and its metabolites have been reported to act on several signaling pathways, including cAMP-response element binding protein (CREB), c-Jun N-terminal kinases, the mitogen-activated protein, macroautophagy, calcium homeostasis, proteasomal degradation and GADD34-eIF2 $\alpha$-ATF4 pathways that participate in AD pathogenesis [29-32]. Moreover, quercetin serves as Sirt1 agonist and acetylcholine-esterase (AchE) inhibitor to ameliorate AD phenotypes [33, 34]. However, there are still some controversial reports. Dietary supplementation of quercetin $(2 \mathrm{mg} / \mathrm{g}$ diet $)$ for 6 weeks has no effects on expression and activities of $\alpha$ and $\beta$ secretase in mice cortex [35]. The expression of neprilysin, heme

A

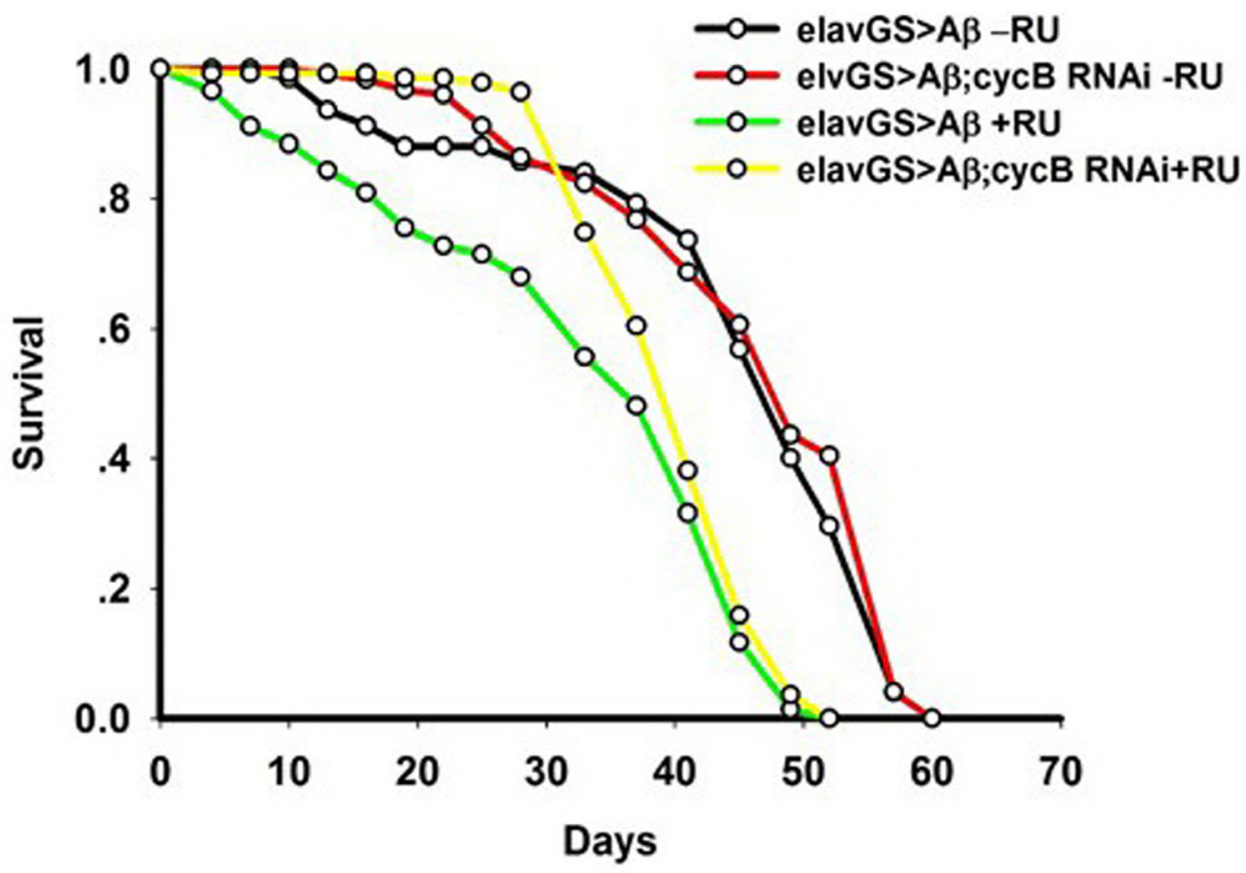

B

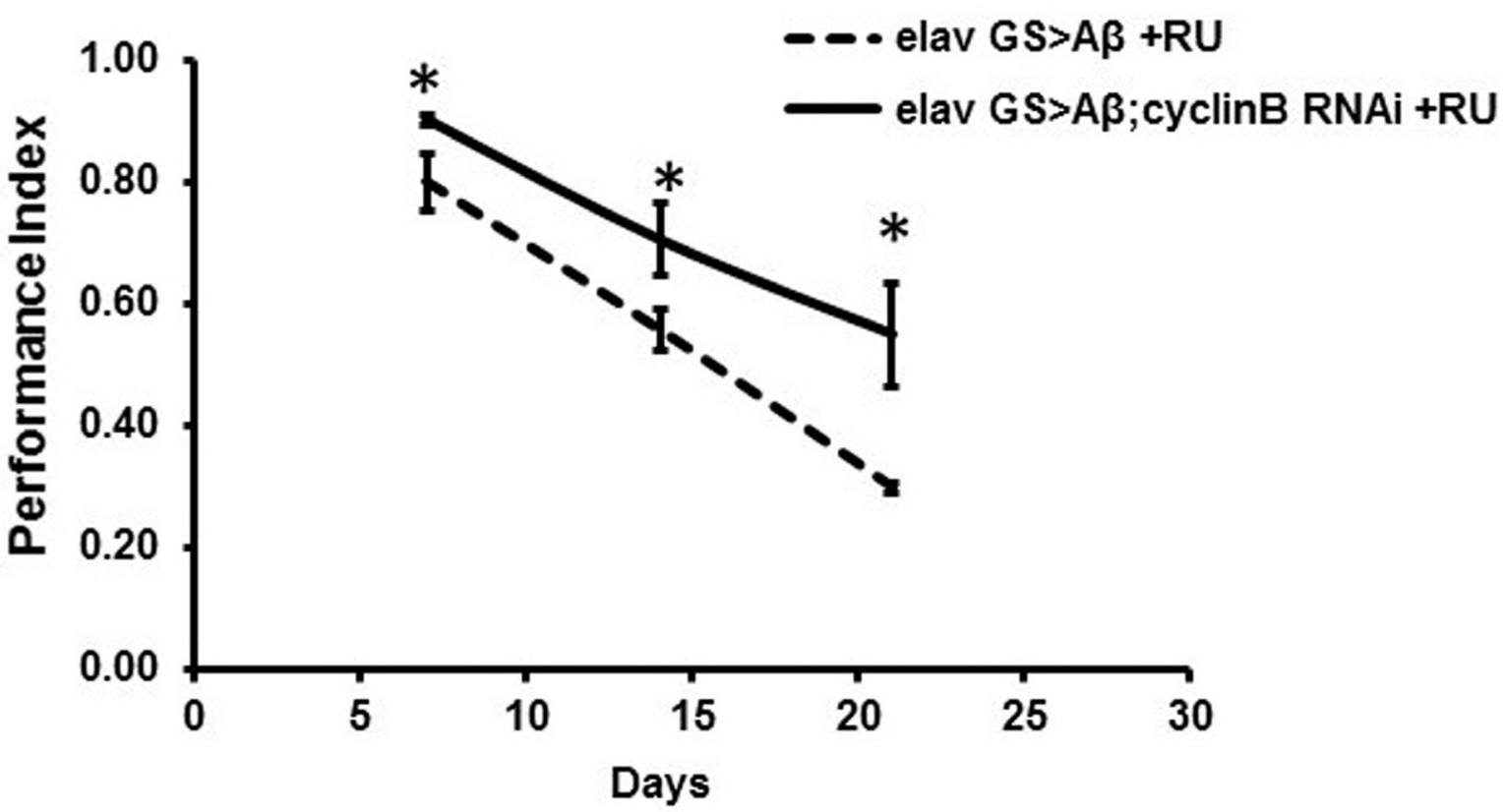

Figure 9: In vivo RNAi of cyclin B ameliorated AD phenotypes in Drosophila. A. The experiments were performed independently for 3 times and representative results were shown. Survival curves were compared using the log-rank test and significant difference was observed between RU induced and uninduced groups $\left(P=4.62276 \times 10^{-18}\right.$ between elavGS $>\mathrm{A} \beta-\mathrm{RU}$ and elavGS $\left.>\mathrm{A} \beta+\mathrm{RU}\right)$. Additionally, cyclin B RNAi extended the lifespan of AD fruit flies $(P=0.000611737$ between elavGS $>$ A $\beta+$ RU and elavGS $>$ A $\beta$;cyclin $\mathrm{B}$ RNAi $+\mathrm{RU})$. B. Climbing abilities were presented as the average performance index (PI) $\pm \mathrm{SEM}(* P<0.05$ between between elavGS $>$ $\mathrm{A} \beta+\mathrm{RU}$ and elavGS $>\mathrm{A} \beta$; cyclin B RNAi $+\mathrm{RU})$. 
oxygenase-1 and $\gamma$-glutamylcysteine synthetase are not changed. Further investigation with transcriptomic analysis is required to clarify the detailed mechanisms.

Using microarray analysis for wild type and AD flies fed with quercetin or control food, we elucidated that quercetin ameliorated AD phenotypes in Drosophila by targeting several signaling pathways, such as DNA replication, FoxO signaling and Hypoxia response via HIF activation. Cell cycle proteins in FoxO signaling such as cyclin B, cyclin B3 and polo as well as DNA replication proteins including $\mathrm{mcm} 2, \mathrm{mcm} 3, \mathrm{mcm} 7$ and PCNA were the hubs of protein-protein interaction network. Their expression was dysregulated by $A \beta$ expression and rescued by quercetin. Our results support the wellrecognized theory that ectopic cell cycle events could mediate neurodegeneration in AD [36]. In AD brains, neurons expressing biomarkers of cell cycle progression and DNA replication are vulnerable to $A \beta$ toxicity. Cyclin B is only expressed in the severely affected brain regions of $\mathrm{AD}$ patients such as subiculum, dentate gyrus, CA1 region hippocampus, 'locus coeruleus, and dorsal raphe nuclei [37-39]. The expression of Swedish double mutant APP (Swe-APP) in differentiated PC12 cells, rat primary cortical neurons and $\mathrm{Tg} 2576$ mice brain tissues increases mRNA and protein level of cyclin B1 [40]. Normally, neurons are arrested at an early stage of the cell cycle and able to re-differentiate. However, cell cycle is allowed to progress into the G2 phase in Alzheimer's disease. G1/S checkpoint has been bypassed and that the cell cycle is arrested in G2 when cyclin B is expressed in neurons. Neurons arrested at the G2/M phase of the cell cycle are susceptible to AD before they die [41, 42]. The mechanism of cell cycle dysregulation induced neurodegeneration could be explained that neurons which are not able to undergo re-differentiation will die via an apoptotic pathway or produce AD pathology such as tau hyperphosphorylation and $A \beta$ deposition that ultimately leads to neuronal cell death [43]. In addition to cyclin B, the expression of PLKs (Drosophila polo homologues) is upregulated in susceptible hippocampal and cortical neurons of $\mathrm{AD}$ patients [44, 45]. A significant association between the genotypes of PLK2 (rs15009 and rs702723) was found in AD [46]. Mechanism study shows PLK1 is elevated during the cell-cycle re-entry of neuronal cells in vitro [47]. Furthermore, inhibition of PLK1 kinase activity or depletion of PLK1 by RNAi reduces A $\beta$ induced neuronal cell death. These results proposed that cell cycle proteins such as cyclin B, cylin B3 and PLKs as possible targets for $\mathrm{AD}$ treatment. Consistent with these reports, we found cyclin $\mathrm{B}$ expression was increased in $\mathrm{AD}$ flies and restored by feeding quercetin both at mRNA and protein level. Additionally, inhibition of cyclin B expression by RNAi could ameliorate AD phenotypes. We proposed that neuroprotective effects of quercetin in $\mathrm{AD}$ were mediated at least partially by targeting cell cycle related pathways. Supporting our findings, in tau protein induced AD Drosophila, ectopic cell-cycle activation mediated by cyclin B and cyclin B3 leads to apoptosis of postmitotic neurons in vivo [48]. Additionally, quercetin has been found to suppress cyclin B expression in liver, breast carcinoma and human leukemic T-cells, which could induce cell cycle arrest, decrease cell proliferation and enhance apoptosis [49-51].

DNA replication is a subsequent cascade for cell cycle re-entry and precedes neuronal cell death in Alzheimer's disease [52, 53]. DNA replication gives rise to neurons with a content of DNA above the diploid level. Neurons with an aneuploid set of chromosomes are rare in the normal brain. In contrast, the number of aneuploid neurons is highly increased in AD [54]. Using fluorescent in situ hybridization, four separate genetic loci on three different chromosomes are found to have replicated in hippocampal pyramidal and basal forebrain neurons in $\mathrm{AD}$ [55]. In our study, we identified DNA replication pathway proteins including $\mathrm{mcm} 2, \mathrm{mcm} 3$, mcm 7 and mus209 (PCNA) were upregulated in AD flies and suppressed after quercetin dietary supplementation. Among them, $\mathrm{mcm} 2, \mathrm{mcm} 3, \mathrm{mcm} 7$ are DNA helicases and PCNA acts as a scaffold to recruit proteins involved in DNA replication. Consistent with our findings, quercetin was reported to inhibit DNA replication in human HL-60 leukemic cells [56]. Lin $\mathrm{HH}$ found quercetin could inhibit DNA helicase in vitro [57]. As an important replication factor, Mcm2 phosphorylation is associated with AD pathology, such as neurofibrillary tangles, neuropil threads, and dystrophic neurites [58]. Mcm2, Ki67 and PCNA expression in neurons and glial cells increases significantly and associates with higher burdens of Alzheimer-type pathology. Taken these findings and our results together, cell cycle disturbances in $\mathrm{AD}$ and related DNA replication may contribute to AD pathology and explain the mechanism of quercetin's therapeutic effects.

$\mathrm{A} \beta$ induced dysregulation of genes involved in cell cycle events are mediated by activation of signaling pathways such as GSK-3 $\beta$ and ERK1/2 in AD $[59,60]$. Interestingly, it has been reported that quercetin could inhibit GSK-3 $\beta$ and ERK1/2 pathways in the brain [61, $62]$. In control flies, these pathways were not activated and quercetin's effects on the expression of cell cycle related genes were not as significant as in AD Drosophila.

Our study revealed that quercetin could ameliorate AD pathogenesis in Drosophila model through modulating the expression of cell cycle related proteins such as cyclin B. It broadened the understanding about the mechanism of quercetin's beneficial effects on AD and provided new insights into the therapeutic methods for neurodegeneration. 
Table 3: Primers for qRT-PCR validation experiments.

\begin{tabular}{|c|c|}
\hline Gene & Primer sequence \\
\hline \multirow{2}{*}{$\mathrm{mcm} 7$} & Forward: 5'-CATCATGACGACCCTAAACG-3' \\
\hline & Reverse: 5'-ACAGCAGATCGAAACGTGAG-3' \\
\hline \multirow{2}{*}{$\mathrm{mcm} 3$} & Forward: 5'-TAATCCGGTGTACGGAAGGT-3' \\
\hline & Reverse: 5'-GTCCAGCATAACGAAGAGCA-3' \\
\hline \multirow{2}{*}{$\mathrm{mcm} 2$} & Forward: 5'-GACGCACGTAATGGACAATC-3' \\
\hline & Reverse: 5'-CTGATCTCCCAGGATCTCGT-3' \\
\hline \multirow{2}{*}{ cyclin B } & Forward: 5'-CAGTTCTTCCGAGAACGTGA-3' \\
\hline & Reverse: 5'-TTCCTTCTTGGTCTCTGCCT-3' \\
\hline \multirow{2}{*}{ polo } & Forward: 5'-ATGGAGCTGCACAAACGTAG-3' \\
\hline & Reverse: 5'-ATAATGCGGTTATCGTGCAA-3' \\
\hline \multirow{2}{*}{ cyclin B3 } & Forward: 5'-TTGCTGACACTCCCAGAGAC-3' \\
\hline & Reverse: 5'-GCGCACTTTGAGGTAGTTGA-3' \\
\hline \multirow{2}{*}{ deadhead } & Forward: 5'-TTTAGCTTGTAAGCGCGAGA-3' \\
\hline & Reverse: 5'-GCGCCACAAATCATAGCATA-3' \\
\hline \multirow{2}{*}{ Actin } & Forward: 5'-AGAAGGACTCGTACGTGGGT-3' \\
\hline & Forward: 5'-CATATCGTCCCAGTTGGTCA-3' \\
\hline
\end{tabular}

\section{MATERIALS AND METHODS}

\section{Fly stocks and maintenance}

Flies were maintained at $25^{\circ} \mathrm{C}$ on $12 \mathrm{~h}: 12 \mathrm{~h}$ light: dark cycle. UAS- ArcA $\beta_{42}$ flies were from Dr. D. Crowther (University of Cambridge, UK). The elav-Gal4 ${ }^{\text {c155 }}$ stocks were from Bloomington Drosophila Stock Center. Cyclin B RNAi line was obtained from Dr. Norbert Perrimon, at Harvard Medical School, and Dr. Jian-Quan Ni at Tsinghua Fly Center. ElavGS line was originally made by Prof. $\mathrm{H}$ Keshishian (Yale, USA). Flies used in all experiments were backcrossed six times into the $w^{1118}$ genetic background. Quercetin was obtained from Jianfeng Health Tech. Co., Ltd (Zhejiang, China). HPLC, Mass spectrometry and NMR was performed to quantify quercetin purified from flowers of Styphnolobium japonicum. Quercetin was dissolved in DMSO and then added to standard yeast/agar (SYA) food at final concentration of $0.44 \mathrm{~g} / \mathrm{L}(1.31 \mathrm{mM})$ which was much lower than those used in mouse model [63]. For control food, DMSO alone was added.

\section{Lifespan analyses}

Lifespan assay was performed as described previously [62]. Mated females were discriminated and transferred into vials with standard sugar-yeast medium supplemented with quercetin or equivalent concentration of DMSO at the density for 10 flies in each vial. Vials were changed 3 times a week and at least 100 in total were analyzed for survival in each group. For lifespan experiments, data are presented as survival curves and analysis was performed using log-rank tests to compare between groups. It is assumed to be significant difference if $P<0.05$.

\section{Climbing assay}

$25 \mathrm{ml}$ plastic pipettes were used to analyze Drosophila climbing ability. Each group contains 3 vials and twenty female flies were cultured in each vial. Flies transferred into an empty pipette. After gently tapped to the bottom, the numbers of flies that could climb to the top (above the $25 \mathrm{ml}$ line) and stayed at bottom (below the $2 \mathrm{ml}$ line) within 45 seconds were recorded. The climbing was analyzed 3 times for every vial at each time point. The performance index (PI) was calculated as described previously [63].

\section{RNA isolation}

50 fly heads were harvested and homogenized in Trizol reagent (ambion). After centrifugation at $12,000 \mathrm{~g}$ for $10 \mathrm{~min}$ at $4{ }^{\circ} \mathrm{C}$, the supernatant was transferred to a new tube and then mixed thoroughly with chloroform. After incubation and centrifugation at $12,000 \mathrm{~g}$ for $15 \mathrm{~min}$ at $4^{\circ} \mathrm{C}$, aqueous phase was transferred into new tubes. RNA was precipitated by isoproponal and washed with $75 \%$ ethanol. Finally, RNA pellets were dissolved in RNase free water. RNA concentration and OD260/280 ratio were measured by ultraviolet spectrophotometer.

\section{Affymetrix Drosophila Genome 2.0 array}

Transcriptomic analysis was performed by Affymetrix Drosophila Genome 2.0 Array according to the 
manufacturer's instructions. Briefly, reverse transcriptase was used to synthesize fist-strand cDNA using oligo dT. After RNA digestion in DNA-RNA hybrid, second strand cDNA was produced accordingly. In vitro transcription was performed with T7 Enzyme to make biotin labeled cRNA (Ambion \#1792 cRNA kit), which was further purified by RNA Binding Beads. After fragmentation, cRNA was hybridized with probes in chips, followed by washing, staining and scanning. Affymetrix GeneChip Command Console Software was used to abstract and analyzed the data. SAM (significance analysis of microarray) of R software and RMA method were used to identify differentially expressed genes (Ratio $\geq 2$ or Ratio $\leq 0.5$ ) as published literature [64].

\section{Gene ontology and pathway enrichment analysis}

KOBAS (KEGG Orthology Based Annotation System) was used to analyze gene ontology and pathway enrichment for dysregulated genes. Gene ontology was analyzed by the databases and divided into three categories: biological process, molecular function and cell component. $P$ values were calculated according to published literature [65]. In order to show the interaction for different terms, GO hierarchy for significant influenced terms $(P<0.05)$ in biological process, molecular function and cell component were drawn. Pathway enrichment were analyzed by KEGG pathway, PID curated, PID BioCarta, PID reactome, BioCyc, Reactome and Panther.

\section{Protein interactions networks assay}

STRING is a database of known and predicted protein interactions. The interactions include direct (physical) and indirect (functional) associations; they are derived from different sources including Genomic Context, High-throughput Experiments, Coexpression and Previous Knowledge. The nodes of network represent the proteins encoded by the dysregulated genes. Different colored lines link of nodes represent types of evidence used in predicting associations. (red line: fusion; green line: neighborhood; blue line: concurrence; purple line: experimental evidence; yellow line : textmining evidence; light blue line: database evidence; black line: coexpression evidence).

\section{Quantitative real-time PCR analysis}

Quantitative real-time PCR (qRT-PCR) analysis was performed to validate the data obtained from microarray. Fist strand cDNA was sysnthesized using PrimeScript ${ }^{\mathrm{TM}}$ RT reagent Kit with gDNA Eraser (RR047A Takara) according manufacturer's instructions. M-MLV reverse transcriptase (Takara). $1 \mu \mathrm{g}$ total RNA was mixed with $2 \mu \mathrm{l}$
gDNA Eraser Buffer, $1 \mu \mathrm{l}$ gDNA EraserRT and RNase free water to a $10 \mu \mathrm{l}$ final volume and incubated at $42^{\circ} \mathrm{C}$ for $5 \mathrm{~min}$. The mixture was further supplemented with $1 \mu \mathrm{l}$ PrimeScript RT Enzyme Mix I, $1 \mu$ l RT Primer Mix, $4 \mu 1$ PrimeScript Buffer 2 and $4 \mu \mathrm{l}$ RNase free water and then incubate at $37^{\circ} \mathrm{C}$ for $15 \mathrm{~min}$ and followed by $85^{\circ} \mathrm{C}$ for 5 sec. qPCR reaction was performed with $2 \times$ SYBR Green PCR Master Mix (Takara) and ABI StepOnePlusTM realtime PCR System (Applied Biosystems) with the program: $95^{\circ} \mathrm{C}$ for $5 \mathrm{~min}$ to denature DNA templates, followed by 40 cycles of $95^{\circ} \mathrm{C}$ for $15 \mathrm{~s}, 60^{\circ} \mathrm{C}$ for $30 \mathrm{~s}$, and $72^{\circ} \mathrm{C}$ for 32 s. The PCR primers were listed in Table 3.

\section{Western analysis}

Western blotting was performed as described previously [66]. 20 fly heads were homogenized and underwent SDS-PAGE before transferred to PVDF membranes (Immobilon-P, Millipore). The membrane was blocked with $5 \%$ milk and incubated with anticyclin B antibody (Santa Cruz Biotechnology sc-15872 which has been proved to be specific and sensitive for western blot [21]), or anti-tubulin monoclonal antibody (1:5000, Sigma) overnight at $4^{\circ} \mathrm{C}$. After incubation with HRP conjugated donkey anti-goat or goat-anti-mouse secondary antibody and reacted with SuperSignal West Pico chemiluminescent substrate (Pierce), tubulin and cyclin B expression measured by exposure to X-Omat BT film (Eastman Kodak)

\section{ACKNOWLEDGMENTS}

The authors thank National Engineering Research Center for Beijing Biochip Technology (CapitalBio) for assistance in microarray analysis.

\section{CONFLICTS OF INTEREST}

There is no potential conflicts of interest for authors.

\section{GRANT SUPPORT}

This work was supported by grant from the National Natural Science Foundation of China (31200804) (to Y. K.); Specialized Research Fund (20120092120065) for the Doctoral Program of Higher Education, Ministry of Education, China (to Y. K.); Students Research Training Program (SRTP) from Southeast University (to Y. K.); Fundamental Research Funds for the Central Universities (2242016K41035), Southeast University, Ministry of Education, China (to Y. K.); Ministry of Science and Technology of China (973 Program 2015CB856300) (to Z.G). National Natural Science Foundation of China (No. 31471110, 81400821) (to Z.G); Natural Science Foundation of Jiangsu Province (BK20140600) (to Z.G). 


\section{REFERENCES}

1. Ittner LM, Gotz J. Amyloid-beta and tau - a toxic pas de deux in Alzheimer's disease. Nat Rev Neurosci. 2011; 12:65-72.

2. Musiek ES, Holtzman DM. Three dimensions of the amyloid hypothesis: time, space and 'wingmen'. Nat Neurosci. 2015; 18:800-806.

3. Sun L, Zhao L, Yang G, Yan C, Zhou R, Zhou X, Xie T, Zhao Y, Wu S, Li X, Shi Y. Structural basis of human gamma-secretase assembly. Proc Natl Acad Sci U S A. 2015; 112:6003-6008.

4. Fan X, Liang Q, Lian T, Wu Q, Gaur U, Li D, Yang D, Mao X, Jin Z, Li Y, Yang M. Rapamycin preserves gut homeostasis during Drosophila aging. Oncotarget. 2015; 6:35274-35283. doi: 10.18632/oncotarget.5895.

5. Bonner JM, Boulianne GL. Drosophila as a model to study age-related neurodegenerative disorders: Alzheimer's disease. Exp Gerontol 2011; 46(5):335-339.

6. Iijima K, Liu HP, Chiang AS, Hearn SA, Konsolaki M, Zhong Y. Dissecting the pathological effects of human Abeta40 and Abeta42 in Drosophila: a potential model for Alzheimer's disease. Proc Natl Acad Sci U S A. 2004; 101:6623-6628.

7. Crowther DC, Kinghorn KJ, Miranda E, Page R, Curry JA, Duthie FA, Gubb DC, Lomas DA. Intraneuronal Abeta, non-amyloid aggregates and neurodegeneration in a Drosophila model of Alzheimer's disease. Neuroscience. 2005; 132:123-135.

8. Bouleau S, Tricoire H. Drosophila models of Alzheimer's disease: advances, limits, and perspectives. J Alzheimers Dis. 2015;45:1015-1038.

9. Li K, Zhu S, Russ HA, Xu S, Xu T, Zhang Y, Ma T, Hebrok M, Ding S. Small molecules facilitate the reprogramming of mouse fibroblasts into pancreatic lineages. Cell Stem Cell. 2014; 14:228-236.

10. Sarkar S, Rubinsztein DC. Small molecule enhancers of autophagy for neurodegenerative diseases. Mol Biosyst. 2008;4:895-901.

11. Brito AF, Ribeiro M, Abrantes AM, Pires AS, Teixo RJ, Tralhao JG, Botelho MF. Quercetin in Cancer Treatment, Alone or in Combination with Conventional Therapeutics? Curr Med Chem. 2015; 22:3025-3039.

12. Panchal SK, Poudyal H and Brown L. Quercetin ameliorates cardiovascular, hepatic, and metabolic changes in diet-induced metabolic syndrome in rats. J Nutr. 2012; 142:1026-1032.

13. Comalada M, Camuesco D, Sierra S, Ballester I, Xaus J, Galvez J, Zarzuelo A. In vivo quercitrin anti-inflammatory effect involves release of quercetin, which inhibits inflammation through down-regulation of the NF-kappaB pathway. Eur J Immunol. 2005; 35:584-592.

14. Lee M, Son M, Ryu E, Shin YS, Kim JG, Kang BW, Cho H, Kang H. Quercetin-induced apoptosis prevents EBV infection. Oncotarget. 2015; 6:12603-12624. doi: 10.18632/ oncotarget.3687.

15. Kang KS, Yamabe N, Wen Y, Fukui M and Zhu BT. Beneficial effects of natural phenolics on levodopa methylation and oxidative neurodegeneration. Brain Res. 2013; 1497:1-14.

16. Ansari MA, Abdul HM, Joshi G, Opii WO, Butterfield DA. Protective effect of quercetin in primary neurons against Abeta(1-42): relevance to Alzheimer's disease. J Nutri Biochem. 2009; 20:269-275.

17. Choi SM, Kim BC, Cho YH, Choi KH, Chang J, Park MS, Kim MK, Cho KH, Kim JK. Effects of Flavonoid Compounds on beta-amyloid-peptide-induced Neuronal Death in Cultured Mouse Cortical Neurons. Chonnam Med J. 2014; 50:45-51.

18. Regitz C, Dussling LM, Wenzel U. Amyloid-beta (Abeta142)-induced paralysis in Caenorhabditis elegans is inhibited by the polyphenol quercetin through activation of protein degradation pathways. Mol Nutr Food Res. 2014; 58:19311940.

19. Sabogal-Guaqueta AM, Munoz-Manco JI, Ramirez-Pineda JR, Lamprea-Rodriguez M, Osorio E, Cardona-Gomez GP. The flavonoid quercetin ameliorates Alzheimer's disease pathology and protects cognitive and emotional function in aged triple transgenic Alzheimer's disease model mice. Neuropharmacology. 2015; 93:134-145.

20. Wong, Ming. La Médecine chinoise par les plantes. Le Corps a Vivre series. 1976. Éditions Tchou.

21. Kwon SY1, Xiao H, Wu C, Badenhorst P. Alternative splicing of NURF301 generates distinct NURF chromatin remodeling complexes with altered modified histone binding specificities. PLoS Genet. 2009; 5:e1000574.

22. Szklarczyk D, Franceschini A, Wyder S, Forslund K, Heller D, Huerta-Cepas J, Simonovic M, Roth A, Santos A, Tsafou KP, Kuhn M, Bork P, Jensen LJ et al. STRING $\mathrm{v} 10$ : protein-protein interaction networks, integrated over the tree of life. Nucleic Acids Res. 2015; 43:D447-452.

23. Shimmyo Y, Kihara T, Akaike A, Niidome T, Sugimoto H. Flavonols and flavones as BACE-1 inhibitors: structureactivity relationship in cell-free, cell-based and in silico studies reveal novel pharmacophore features. Biochim Biophys Acta. 2008; 1780:819-825.

24. Ho L, Ferruzzi MG, Janle EM, Wang J, Gong B, Chen TY, Lobo J, Cooper B, Wu QL, Talcott ST, Percival SS, Simon JE, Pasinetti GM. Identification of brain-targeted bioactive dietary quercetin-3-O-glucuronide as a novel intervention for Alzheimer's disease. FASEB J. 2013; 27:769-781.

25. Jimenez-Aliaga K, Bermejo-Bescos P, Benedi J, MartinAragon S. Quercetin and rutin exhibit antiamyloidogenic and fibril-disaggregating effects in vitro and potent antioxidant activity in APPswe cells. Life Sci. 2011; 89:939-945.

26. Ono K, Yoshiike Y, Takashima A, Hasegawa K, Naiki $\mathrm{H}$, Yamada M. Potent anti-amyloidogenic and fibril- 
destabilizing effects of polyphenols in vitro: implications for the prevention and therapeutics of Alzheimer's disease. J Neurochem. 2003; 87:172-181.

27. Smith JV, Luo Y. Elevation of oxidative free radicals in Alzheimer's disease models can be attenuated by Ginkgo biloba extract EGb 761. J Alzheimers Dis. 2003; 5:287-300.

28. Kraus B, Wolff H, Heilmann J, Elstner EF. Influence of Hypericum perforatum extract and its single compounds on amyloid-beta mediated toxicity in microglial cells. Life Sci. 2007; 81:884-894.

29. Tchantchou F, Lacor PN, Cao Z, Lao L, Hou Y, Cui C, Klein WL and Luo Y. Stimulation of neurogenesis and synaptogenesis by bilobalide and quercetin via common final pathway in hippocampal neurons. J Alzheimers Dis. 2009; 18:787-798.

30. Ho L, Ferruzzi MG, Janle EM, Wang J, Gong B, Chen TY, Lobo J, Cooper B, Wu QL, Talcott ST, Percival SS, Simon JE, Pasinetti GM. Identification of brain-targeted bioactive dietary quercetin-3-O-glucuronide as a novel intervention for Alzheimer's disease. FASEB J. 2013; 27:769-781.

31. Shi C, Wu F and Xu J. H2O2 and PAF mediate Abeta1-42induced $\mathrm{Ca} 2+$ dyshomeostasis that is blocked by EGb761. Neurochem Int. 2010; 56:893-905.

32. Hayakawa M, Itoh M, Ohta K, Li S, Ueda M, Wang MX, Nishida E, Islam S, Suzuki C, Ohzawa K, Kobori M, Inuzuka T, Nakagawa T. Quercetin reduces eIF2alpha phosphorylation by GADD34 induction. Neurobiol Aging. 2015; 36:2509-2518.

33. Islam MR, Zaman A, Jahan I, Chakravorty R and Chakraborty S. In silico QSAR analysis of quercetin reveals its potential as therapeutic drug for Alzheimer's disease. J Young Pharm. 2013; 5:173-179.

34. Valero T. Mitochondrial biogenesis: pharmacological approaches. Curr Pharm Design. 2014; 20:5507-5509.

35. Huebbe P, Wagner AE, Boesch-Saadatmandi C, Sellmer F, Wolffram S, Rimbach G. Effect of dietary quercetin on brain quercetin levels and the expression of antioxidant and Alzheimer's disease relevant genes in mice. Pharmacol Res. 2010; 61:242-246.

36. Yurov YB, Vorsanova SG, Iourov IY. The DNA replication stress hypothesis of Alzheimer's disease. ScientificWorldJournal. 2011; 11:2602-2612.

37. Vincent I, Jicha G, Rosado M, Dickson DW. Aberrant expression of mitotic cdc2/cyclin B1 kinase in degenerating neurons of Alzheimer's disease brain. J Neurosci. 1997; 17:3588-3598.

38. Nagy Z, Esiri MM, Cato AM, Smith AD. Cell cycle markers in the hippocampus in Alzheimer's disease. Acta Neuropathol. 1997; 94:6-15.

39. Busser J, Geldmacher DS, Herrup K. Ectopic cell cycle proteins predict the sites of neuronal cell death in Alzheimer's disease brain. J Neurosci. 1998; 18:2801-2807.

40. Ahn KW, Joo Y, Choi Y, Kim M, Lee SH, Cha SH, Suh
YH, Kim HS. Swedish amyloid precursor protein mutation increases cell cycle-related proteins in vitro and in vivo. J Neurosci. 2008; 86:2476-2487.

41. Nagy Z, Esiri MM, Smith AD. The cell division cycle and the pathophysiology of Alzheimer's disease. Neuroscience. 1998; 87:731-739.

42. Yang Y, Mufson EJ and Herrup K. Neuronal cell death is preceded by cell cycle events at all stages of Alzheimer's disease. J Neurosci. 2003; 23:2557-2563.

43. Lee HG, Casadesus G, Zhu X, Castellani RJ, McShea A, Perry G, Petersen RB, Bajic V, Smith MA. Cell cycle reentry mediated neurodegeneration and its treatment role in the pathogenesis of Alzheimer's disease. Neurochem Int. 2009; 54:84-88.

44. Harris PL, Zhu X, Pamies C, Rottkamp CA, Ghanbari HA, McShea A, Feng Y, Ferris DK, Smith MA. Neuronal polo-like kinase in Alzheimer disease indicates cell cycle changes. Neurobiol Aging. 2000; 21:837-841.

45. Mbefo MK, Paleologou KE, Boucharaba A, Oueslati A, Schell H, Fournier M, Olschewski D, Yin G, Zweckstetter M, Masliah E, Kahle PJ, Hirling H, Lashuel HA. Phosphorylation of synucleins by members of the Polo-like kinase family. J Bio Chem. 2010; 285:2807-2822.

46. Bufill E, Roura-Poch P, Sala-Matavera I, Anton S, Lleo A, Sanchez-Saudinos B, Tomas-Abadal L, Puig T, Abos J, Bernades S, Clarimon J, Blesa R. Reelin signaling pathway genotypes and Alzheimer disease in a Spanish population. Alzheimer Dis Assoc Disord. 2015; 29:169-172.

47. Song B, Davis K, Liu XS, Lee HG, Smith M, Liu X. Inhibition of Polo-like kinase 1 reduces beta-amyloidinduced neuronal cell death in Alzheimer's disease. Aging (Albany NY). 2011; 3:846-51. doi: 10.18632/aging.100382.

48. Dias-Santagata D1, Fulga TA, Duttaroy A, Feany MB. Oxidative stress mediates tau-induced neurodegeneration in Drosophila. J Clin Invest. 2007; 117:236-245.

49. Casella ML, Parody JP, Ceballos MP, Quiroga AD, Ronco MT, Frances DE, Monti JA, Pisani GB, Carnovale $\mathrm{CE}$, Carrillo MC and de Lujan Alvarez M. Quercetin prevents liver carcinogenesis by inducing cell cycle arrest, decreasing cell proliferation and enhancing apoptosis. Mol Nutri Food Res. 2014; 58:289-300.

50. Choi JA, Kim JY, Lee JY, Kang CM, Kwon HJ, Yoo YD, Kim TW, Lee YS and Lee SJ. Induction of cell cycle arrest and apoptosis in human breast cancer cells by quercetin. Int J Oncol. 2001; 19:837-844.

51. Yoshida M, Yamamoto M, Nikaido T. Quercetin arrests human leukemic T-cells in late G1 phase of the cell cycle. Cancer Res. 1992; 52:6676-6681.

52. Lopes JP, Oliveira CR and Agostinho P. Cell cycle reentry in Alzheimer's disease: a major neuropathological characteristic? Curr Alzheimer Res. 2009; 6:205-212.

53. Yang Y, Geldmacher DS, Herrup K. DNA replication precedes neuronal cell death in Alzheimer's disease. J Neurosci. 2001; 21(8):2661-2668. 
54. Mosch B, Morawski M, Mittag A, Lenz D, Tarnok A, Arendt T. Aneuploidy and DNA replication in the normal human brain and Alzheimer's disease. J Neurosci. 2007; 27:6859-6867.

55. Bonda DJ, Evans TA, Santocanale C, Llosa JC, Vina J, Bajic V, Castellani RJ, Siedlak SL, Perry G, Smith MA, Lee HG. Evidence for the progression through S-phase in the ectopic cell cycle re-entry of neurons in Alzheimer disease. Aging (Albany NY). 2009; 1:382-8. doi: 10.18632/ aging. 100044.

56. Boege F, Straub T, Kehr A, Boesenberg C, Christiansen K, Andersen A, Jakob F, Kohrle J. Selected novel flavones inhibit the DNA binding or the DNA religation step of eukaryotic topoisomerase I. J Biol Chem. 1996; 271:22622270.

57. Lin HH, Huang CY. Characterization of flavonol inhibition of DnaB helicase: real-time monitoring, structural modeling, and proposed mechanism. J Biomed \& Biotech. 2012; 2012:735368.

58. Wharton SB, Williams GH, Stoeber K, Gelsthorpe CH, Baxter L, Johnson AL, Ince PG, Mrc C. Expression of Ki67, PCNA and the chromosome replication licensing protein $\mathrm{Mcm} 2$ in glial cells of the ageing human hippocampus increases with the burden of Alzheimer-type pathology. Neuroscience Lett. 2005; 383:33-38.

59. Hernández-Ortega $\mathrm{K}$, Arias C. ERK activation and expression of neuronal cell cycle markers in the hippocampus after entorhinal cortex lesion. J Neurosci Res. 2012; 90:2116-2126.

60. Ahn KW, Joo Y, Choi Y, Kim M, Lee SH, Cha SH, Suh $\mathrm{YH}, \mathrm{Kim}$ HS. Swedish amyloid precursor protein mutation increases cell cycle-related proteins in vitro and in vivo. $\mathrm{J}$ Neurosci Res. 2008; 86:2476-2487.
61. Boku S, Nakagawa S, Toda H, Kato A, Takamura N, Omiya Y, Inoue T, Koyama T. ROCK2 regulates bFGF-induced proliferation of SH-SY5Y cells through GSK-3 $\beta$ and $\beta$-catenin pathway. Brain Res. 2013; 1492:7-17. 62. J Biol Chem. 2003;278:34783-34793.

62. Kong Y, Wu J, Yuan L. MicroRNA expression analysis of adult-onset Drosophila Alzheimer's disease model. Curr Alzheimer Res. 2014;11:882-891.

63. Kong Y, Liang X, Liu L, Zhang D, Wan C, Gan Z, Yuan L.High Throughput Sequencing Identifies MicroRNAs Mediating $\alpha$-Synuclein Toxicity by Targeting NeuroactiveLigand Receptor Interaction Pathway in Early Stage of Drosophila Parkinson's Disease Model. PLoS One. 2015; 10:e0137432.

64. Irizarry RA, Hobbs B, Collin F, Beazer-Barclay YD, Antonellis KJ, Scherf U, Speed TP. Exploration, normalization, and summaries of high density oligonucleotide array probe level data. Biostatistics. 2003; 4:249-264.

65. Mao X, Cai T, Olyarchuk JG, Wei L. Automated genome annotation and pathway identification using the KEGG Orthology (KO) as a controlled vocabulary. Bioinformatics. 2005; 21:3787-3793.

66. Kong Y, Ruan L, Qian L, Liu X, Le Y. Norepinephrine promotes microglia to uptake and degrade amyloid beta peptide through upregulation of mouse formyl peptide receptor 2 and induction of insulin-degrading enzyme. J Neurosci. 2010; 30:11848-11857. 